\title{
A conceptual framework for alternative farmers' strategic choices: \\ The case of French organic market gardening microfarms
}

\begin{abstract}
Alternative farming systems are challenging classical agronomic frameworks because their aim is to promote human and ecosystems welfare rather than profit maximization. The objective of our work was to understand how alternative farmers build their strategic choices. Through a multiple-case qualitative study of 14 organic market gardening microfarms in the northern half of France, we developed a systemic conceptual framework in which strategic decision making is integrated with a wide range of social and environmental aspirations. As these various aspirations can be in tension, it is relevant to consider trade-offs between them to study the viability of alternative farms.
\end{abstract}

\section{Keywords}

Agroecology; Permaculture; Organic horticulture; Farming systems; Small farms; Systemic approach; Trade-offs 


\section{Introduction}

\subsection{The challenge of alternative farmers' strategic choices}

Farmers can have other objectives than maximizing their income (Brossier et al. 2003). Yet most classical agronomic decision-making frameworks and tools were designed to support farmers to generate profit while increasing yields or reducing costs (Benoit et al. 1988; Brossier et al. 2003; Brummel and Nelson 2014). In this regard, such frameworks are in line with the dominant agricultural model of the twentieth century, focused primarily on increasing production efficiency regardless of social and environmental consequences (Howard 1940; Hernandez 1977; Altieri 1989, Hervieu and Purseigle 2013). However, increasingly strong social movements are campaigning to promote food systems that preserve natural resources and the environment, respect farmers and their culture, offer fair-trade and healthy food, and contribute to the vitality of rural communities (Holmes 2006 ; Deverre and Lamine 2010; Holt Giménez and Shattuck 2011; Fernandez et al. 2013). Farmers involved in these movements may be characterized as "alternative" as they call for a shift with the dominant model and prioritize the fulfillment of social and environmental aspirations rather than profit maximization (Beus et Dunlap 1990; Fernandez et al. 2013). Understanding and supporting alternative farmers' decision-making thus requires conceptual frameworks which fully consider their non-pecuniary aspirations. An increasing number of scientific works has examined farmers' decision-making in the light of non-economic aspirations (Brummel and Nelson 2014). However, most were directed toward understanding the impact of farmer's values and motivations on specific issues such as sustainable land-use (Girard et al. 2008, Schmitzberger et al. 2005), labor allocation (Howley et al. 2014), or adoption of new technics or equipment (Greiner and Gregg 2011; Brudermann et al. 2013). As far as we know, no research to date has proposed a framework to link farmers' non-pecuniary aspirations to the sum of their strategic choices. Strategic choices are defined by Marshall et al. (2013) as all choices which concern farm structure and long-term organization. Since strategic choices determine farm trajectories (Marshall et al. 2013), they are a key point in assessing farms' viability, conceived as internal economic and social sustainability (Yunlong and Smit, 1994; Hansen and Jones 1996; Ba and Aubry 2011). Studying the viability of alternative farms stems from a real societal need, as these initiatives are often perceived as utopian, precarious, and ephemeral (Boutinet 2012). The objective of our work was to develop a conceptual framework for a systemic understanding of how alternative farmers build their strategic choices. It was based on a multiple-case study carried out on 14 market gardening microfarms 
in the northern half of France. This conceptual framework was meant to be a first step in the development of a practical tool to support microfarmers in their strategic decision-making. It was presented and discussed with practitioners on the field.

\subsection{Market gardening microfarms: growing alternative farming systems}

Microfarms are alternative farming systems arousing growing interest and media coverage in France. Popularized by alternative practitioners (Fortier 2014; Hervé Gruyer 2014), the term "microfarms" denotes small-sized commercial market gardens sharing some important characteristics: cultivated acreage smaller than official recommendations for market gardening; community oriented marketing through short supply chains; wide diversity of plants cultivated; and low level of motorization and investment. As microfarmers claim to develop agricultural systems contributing to ecosystem health and social welfare, they promote organic farming and take inspiration from a broad range of alternative practices and philosophies such as biointensive sustainable mini-farming (Jeavons 2001); small-scale organic farming (Coleman 1995, 1999, 2009); microfarming (Fortier 2014); conservation agriculture practices for market gardening (Bodiou 2009); natural farming (Fukuoka 1992), permaculture (Mollison and Holmgren 1981; Holmgren 2002; Whitefield 2004, Ferguson and Lovell 2014). Scientific literature mentions small-scale direct-selling diversified market gardens (Bon et al. 2010; Navarrete 2009) but no scientific study has been yet published specifically on microfarms. However, informal discussions with scientists and practitioners show that these initiatives are spreading in various countries over the world mainly in industrialized countries such as the United Kingdom, Belgium, Netherlands, Ireland, Canada, the United States but also in developing countries such as the Democratic Republic of the Congo.

\section{Material, methods and concepts}

\subsection{An agroecological case study combining systemic agronomy and social sciences}

Microfarms are complex systems, like all diversified market gardening operations embedded in short local supply chains (Bressoud et al. 2009; Bon et al. 2010; Aubry et al. 2011). As such they require systemic approaches (Morin 2005). To address the issue of microfarmers' strategic choices, we utilized the concepts of systemic agronomy (Landais et al., 1988; Brossier et al. 2003; Laurent et al. 2003; Marshall et al. 2013). We also drew on social science methods in order to study aspirations, perceptions, and subjectivity of farmers (Milleville 
1987, Chia et al. 1991). We chose to implement a qualitative inductive analysis based on a multiple-case study (Eisenhardt 1989; Yin 2009), which is described below. By combining systemic agronomy and social sciences, we designed this project in accordance with the transdisciplinary character of agroecology, as a scientific approach that draws on the complementarity of the social, ecological and agronomic sciences to study food systems sustainability (Dalgaard et al. 2003; Francis et al. 2003, Méndez et al. 2013).

\subsection{A farm sampling based on theoretical relevance}

In 2014, France counted 6,529 organic market gardens, representing a total surface area of 16,568 ha (Agence Bio 2014) but no specific statistics exist about microfarms. However, microfarms iniatives are most of the time carried out by people with no agricultural background, who are not conditioned by conventional agricultural standards and see farming as a way to fulfil their alternative aspirations. Moreover, these people without family agricultural capital and land are attracted by microfarms because they require only a small surface area and a low level of investment. In 2014, 3,215 new farms were created in France in 2014. Of these, $217(1,6 \%)$ can be categorized as organic market gardens, using the criteria of (i) selling through short-supply chains, and (ii) led by people with no agricultural background (Jeunes Agriculteurs 2013). Among these projects, the part of microfarms is difficult to estimate, but discussions with agricultural extension agents suggest that it is likely significant. In line with the case study approach, we identified 14 microfarms north of the Loire River through "alternative market gardening" networks. They were not intended to be a representative sample but selected for their theoretical relevance (Eisenhardt 1989; Siggelkow 2007). They shared the same main characteristics:

- Market gardening was the main income-earning activity.

- Cultivated area was below 1,5 hectare by full-time equivalent, which is the minimal size generally recommended by French official agricultural development agencies for diversified market gardening (GAB/FRAB 2009).

- No artificial fertilizers and phytosanitary products were used, with or without organic agriculture certification.

- More than 30 "production types" were grown per farm. We use this term for types of vegetables or herbs which are distinguished by consumers and in marketing even though they belong to the same botanic species (for example cherry tomatoes vs beef tomatoes or broccoli vs cauliflower). Products from fruit shrubs and trees were not counted. 
- Farmers sold their production through short supply chains: direct selling to consumers or with only one intermediary (Aubry et al. 2011).

- Farmers referred to alternative sources of inspiration (as presented in the introduction) and claimed strong social and environmental aspirations.

Structural data are presented in Table 1. The farms were managed by one to three farmers, male or female, aged between 25 and 55, generally with a high level of education and a wide range of career paths. Only two farms were led by people with an agricultural background. The farm's creation was always recent ( 1 to 9 years ago), which indicates the emergence of these farming models, at least in the regions studied. In the rest of this article, the studied farms will be named in reference to Table 1.

\subsection{Data collection through qualitative interviews}

Semi-structured interviews were held on the 14 farms studied. Each interview lasted one full day and started with a trip around the farm. Following the framework of practices analysis described by Landais et al. (1988), questions were asked to the farmer about his or her motivations for choosing crops, technics, management options and equipment which were observable on the field. In a second time, a more detailed interview was carried out in the farmers' house. The main themes to discuss were organized in an interview framework as suggested by Oliver De Sardan (2009) and were inspired by systemic agronomy diagnosis (Marshall et al. 2003): (i) farmers history and background, (ii) farm history, design and structure, (iii) cropping practices, (iv) marketing strategies, (v) equipment and investment, (vi) economic results. We systematically questioned the reasons motivating each strategic choice. Questions were asked as spontaneously as possible in reaction to farmers' speech to set up an informal communication mode creating quality interaction between farmers and researchers (Olivier de Sardan 2009; Beaud and Weber 2010).

\subsection{Building the conceptual framework}

To process the interview content, we followed a method of qualitative analysis (Elo and Kyngäs 2008) and used the coding and matrix tools described by Miles and Huberman (1984) in the specific context of multiple-case study (Eisenhardt 1989; Yin 2009). The general aim of this approach was to build more and more abstract categories on the basis of an iterative cross analysis of interview content and to reveal relations between these categories. From this process, 6 types of strategic choices structuring microfarms emerged. 
Table 1: presentation of the 14 studied microfarms

\begin{tabular}{|c|c|c|c|c|c|c|c|c|c|}
\hline Region & Farm & $\begin{array}{l}\text { Age of the } \\
\text { farm } \\
\text { (years } \\
\text { since } \\
\text { creation) }\end{array}$ & $\begin{array}{c}\text { Farmers' } \\
\text { labor* } \\
\text { (full-time } \\
\text { equivalent**) }\end{array}$ & $\begin{array}{c}\text { Employees' } \\
\text { labor } \\
\text { (full-time } \\
\text { equivalent) }\end{array}$ & $\begin{array}{c}\text { Volunteers' } \\
\text { labor } \\
\text { (full-time } \\
\text { equivalent) }\end{array}$ & $\begin{array}{l}\text { Market gardening } \\
\text { acreage per labor } \\
\text { unit ** } \\
\text { (m2/ full-time } \\
\text { equivalent) }\end{array}$ & $\begin{array}{c}\text { Share of } \\
\text { cultivated area } \\
\text { under } \\
\text { greenhouses }\end{array}$ & $\begin{array}{l}\text { Production } \\
\text { types grown } \\
\text { on the farm }\end{array}$ & Motorization level \\
\hline Brittany & $\mathbf{A}$ & 2 & 1 & 0 & 0 & 8000 & $13 \%$ & 63 & Hand labor + small tractor \\
\hline \multirow{2}{*}{$\begin{array}{l}\text { Pays de la } \\
\text { Loire }\end{array}$} & $\mathbf{B}$ & 3 & 1 & 0 & 0.5 & 3000 & $18 \%$ & 55 & Hand labor + tiller \\
\hline & $\mathbf{C}$ & 5 & 1 & 1.2 & 0 & 8982 & $7 \%$ & 40 & Hand labor + small tractor \\
\hline \multirow{2}{*}{ Centre } & D & 1 & 3 & 0 & 1 & 1800 & $9 \%$ & 30 & Hand labor \\
\hline & $\mathbf{E}$ & 5 & 2 & 0.7 & 0 & 6600 & $10 \%$ & 50 & Hand labor + small tractor \\
\hline \multirow{2}{*}{ Normandy } & $\mathbf{F}$ & 3 & 2 & 0 & 1 & 5000 & $10 \%$ & 50 & Hand labor + small tractor \\
\hline & G & 9 & 0.5 & 3 & 0.5 & 1250 & $9 \%$ & 80 & Hand labor + horse draught \\
\hline \multirow{6}{*}{ Lorraine } & $\mathbf{H}$ & 3 & 1 & 0 & 0.3 & 9231 & $58 \%$ & 50 & Hand labor + tiller \\
\hline & $\mathbf{I}$ & 5 & 2 & 0 & 0 & 3500 & $14 \%$ & 70 & Hand labor + tiller \\
\hline & $\mathbf{J}$ & 3 & 2 & 0 & 0 & 12000 & $1 \%$ & 55 & Hand labor + small tractor \\
\hline & $\mathbf{K}$ & 4 & 2 & 0 & 0 & 5000 & $10 \%$ & 35 & Hand labor + small tractor \\
\hline & $\mathbf{L}$ & 5 & 1 & 0 & 0.3 & 6538 & $18 \%$ & 40 & Hand labor + tiller \\
\hline & $\mathbf{M}$ & 1 & 2 & 0 & 0.3 & 5217 & $15 \%$ & 50 & Hand labor + tiller \\
\hline Alsace & $\mathbf{N}$ & 4 & 2 & 0 & 0.2 & 9091 & $10 \%$ & 60 & Hand labor + tiller \\
\hline
\end{tabular}

All to a permaculture training center based on the farm (we estimated that they dedicated 0.5 full-time equivalent to farming activities).

** Full-time equivalent were estimated by farmers and correspond to an average workload from $35 \mathrm{~h}$ to $50 \mathrm{~h}$ per week.

*** Including farmers'. employees' and volunteers' labor. 
Our analysis showed that farmers explained these strategic choices by a wide range of justifications, that we called strategic determinants. In accordance with systemic agronomy decisional models, these strategic determinants were divided into two conceptual categories: (i) farmers' aspirations which were grouped into five types, (ii) farmer's perception of their situation (Brossier et al. 2003; Marshall et al. 2013). To describe the relations between conceptual categories of our framework, we used the concepts of coherence, trade-offs, and adaptation from systemic agronomy, and the concept of interdependence from complexity sciences. The coherence concept proposes that farmers have good reasons to do what they do and that strategic choices can be explained rationally by their aspirations and perception (Brossier et al. 2003). As farmers' aspirations are multiple, complex and can be in tension, farmers have to make trade-offs when they take strategic decisions. It means that they try to find an acceptable balance in the fulfillment of their various aspirations (Marshall et al. 2013). The theory of adaptive behavior (Brossier et al. 2003; Marshall et al. 2013) emphasizes that farmers' aspirations - desired reality - are often modified or adjusted to take into account the opportunities and constraints of their situation - perceived reality - because farming is a located, site-specific activity (McCown et al. 2009; Martin 2015). Our interviews showed that farmers' strategic choices as mutually interdependent, each choice conditioning the others (Le Moigne 1994). It is thus necessary to consider them globally rather than individually (Morin 2005).

\subsection{Discussing the conceptual framework in the field}

Conceptual frameworks developed by scientists have to be tested on the field (Bourdieu 1992). Moreover, farmers' involvement in research processes is crucial for orienting farming systems towards more sustainability (Altieri 1989). From this perspective, we presented and discussed our work with 48 market gardening professionals: farmers at each microfarm (20 people), three separate groups of other market gardening practitioners (20 people), market gardening teachers from state agriculture schools (4 people), and organic market gardening advisors (4 people). Each presentation described the way the framework was built, its different conceptual categories and an illustration of its use for understanding specific microfarms case-studies. Each presentation was followed by an open and informal group discussion about the conceptual framework and its use for supporting farmers' decisionmaking. Practitioners' reactions to the framework were analyzed using the concepts of credibility, saliency and legitimacy defined by Cash et al. (2003). 


\section{Results}

\subsection{The determinants of microfarmers' strategic choices}

\subsubsection{A global life project with strong environmental and social aspirations}

All farmers have aspirations that define the project of their farming system (Marshall et al. 2013). Microfarmers' aspirations of the sample can be grouped into 5 types: (i) decent income, (ii) acceptable workload, (iii) autonomy, (iv) quality of life and work, (v) search for meaning and commitment. The 14 studied microfarms referred to each of these 5 types of aspirations to justify their strategic choices but each aspiration type covered a range of specific aspirations which varied among the farms as shown in Figure 1. During the interviews, market gardeners strongly insisted on the social and environmental dimensions of their aspirations at the farm and regional level. This echoed their sources of inspiration, for example permaculture (Holmgren 2002) or organic farming (Darnhofer et al. 2010), which both stress the need to reconcile human well-being (social dimension) and ecosystem health (environmental dimension). Some of these aspirations, for example maintaining a decent income and acceptable workload, seemed to be more social, whereas other aspirations such as the creation of rich ecosystems or preservation of rare resources reflect essentially environmental concerns. However, microfarmers insisted that many of these aspirations relate to both human and ecosystem welfare, which were conceived of as closely interwoven. For example, energetic autonomy on the farm was seen as the same time as a way to preserve rare resources (environmental dimension) and to be less dependent from big energy companies (social dimension). Microfarmers were no exception as regards the necessity of creating economic value as well as rationalizing, organizing and optimizing their production, all of which are underpinned by the "merchant world" and "industrial world" logics as defined by Boltanski and Thévenot (2006). Yet these farmers aimed not to maximize their profit but to obtain a "guaranteed minimum" so that they and their family could live decently. This minimum standard varied among farmers, from $900 €$ to $1800 €$ monthly for one person, depending on their desired lifestyle. In this respect, generating an income was perceived as a social rather than an economic aspiration. The need to create an income and to organize production in order to ensure acceptable workload did of course have a strong impact on microfarmers' strategic choices. However, as shown in Figure 1, these farmers attached central importance in their project to a wide range of other aspirations which belong to the "world of inspiration" and the "civic world" described in the theoretical framework of Boltanki and Thévenot (2006). The "world of inspiration" values beauty, pleasure and 
meaning, while the "civic world" focuses on the community's welfare. In this regard, their project is not a business project, but a life project built as a personal and political act, an expression of each farmer's identity and aspirations for his/her future and that of society. It is therefore essential to consider all microfarmers' aspirations if we are to understand their strategic choices. Interpreting their strategies from a purely commercial or industrial point of view could lead us to conclude that these strategies are not optimal, when in fact they are contributing to the aesthetics of the living environment, to the pleasure to work, to the search for improved social relations in the community, or to the quality of ecosystems.

\subsubsection{Farmers' perception of their specific situation}

In implementing their ideal life project, the studied microfarmers had to adapt it to take into account the specificity of their situation, which is all the opportunities and constraints they perceived on their farm and in its environment (Brossier et al. 2003). As shown in Table 2, the 14 studied microfarms justified their strategic choices in reference to 3 aspects of their situation: (i) site specificity, (ii) farmer's human and material opportunities and constraints, (iii) human and material opportunities and constraints of local community. Thirteen microfarms out of 14 mentioned that they adapted their strategic choices to climatic and soil conditions, and 11 to local ecological conditions because they said that they "wished to work with nature rather than against it". Likewise, farmers from 11 microfarms said that their concerns about human welfare lead them to adopt strategies that respect the needs of individuals working on the farm, related to their physical weaknesses or their temperament for example. Microfarmers' social and environmental aspirations were reflected in a desire for local integration in the use of material and human resources, and in the building of their commercial and social networks. Their perception of local organic matter availability (12 microfarms out of 14), existing short supply channels (14), local consumers' habits (14), and from the psychological and practical support they could get from neighbors, friends and family (9) was thus particularly relevant from a strategic point of a view. Although the local scale was given preference, 3 microfarms also relied on larger networks to access more distant resources or customers, especially through the internet. The importance of thinking and acting in accordance with the specific characteristics of the social and environmental context - with people and place - can be related to the "Observe and interact" permaculture principle (Holmgren 2002) that has inspired several microfarmers. 
Table 2: microfarmers' perception of their situation determining strategic choices

\begin{tabular}{|c|c|}
\hline & Situation aspects mentioned during the interviews \\
\hline \multirow{11}{*}{ Site specificity (14) } & Available surface area (11) \\
\hline & Production site parceling (3) \\
\hline & Land tenure $(6)$ \\
\hline & Site history (7) \\
\hline & Soil quality (13) \\
\hline & Climatic and microclimatic conditions (13) \\
\hline & Site landscape and ecology (11) \\
\hline & Site topography (2) \\
\hline & Distance to a road (3) \\
\hline & Access to water and electricity (6) \\
\hline & Distance to farmers' house (10) \\
\hline \multirow{5}{*}{$\begin{array}{l}\text { Farmers' human and material } \\
\text { opportunities and constraints (14) }\end{array}$} & Farmer's skills and knowledge (13) \\
\hline & Farmers' physical condition or temperament (11) \\
\hline & Personal savings (10) \\
\hline & Bank loans or debts to pay off (4) \\
\hline & Existing equipment on the farm (4) \\
\hline \multirow{7}{*}{$\begin{array}{l}\text { Human and material opportunities and } \\
\text { constraints of local community (14) }\end{array}$} & Consumers' number, distance, eating habits (14) \\
\hline & Preexistence of short food supply chains in the area (14) \\
\hline & Local sources of organic matter (12) \\
\hline & Local support to the microfarm (10) \\
\hline & Local farmers' networks (7) \\
\hline & Family and friends in the neighborhood willing to help (9) \\
\hline & Neighbors with specific skills willing to help (9) \\
\hline
\end{tabular}




\subsection{A variety of integrated strategic choices}

We grouped the strategic choices of the studied microfarms into six categories: (i) marketing, (ii) community integration, (iii) investment, (iv) labor organization, (v) technical and ecological management, (vi) temporal and spatial organization of cultivated diversity. Each category embraces a variety of strategic choices whose presence, importance and combination varied among the farms.

\subsubsection{Marketing, community integration, investment and labor organization}

In line with their aspirations to be involved in local life all microfarmers from our sample sold through short supply chains. However, microfarms' marketing choices differed in the nature of such chains, their combination and their selling period (Table 3). To fulfill short supply chains requirement, microfarms commercialized a wide diversity of vegetable and herb production types (from 35 to 70) which was much wider than in larger organic market gardens observed in the southern part of France by Navarrete (2009) in long supply chains (5 vegetables types in average) or in short supply chains (30 vegetables types in average). Short supply chains contributed to building interpersonal relationships within the local community, which went well beyond the commercial ties and were strengthened by diverse nonagricultural activities (Table 3). This strategic social anchorage within the community made it possible for microfarmers to benefit from a wide range of material and immaterial resources (Table 3) through non-monetary exchanges, loans or gifts. These "community resources" were part of the farms' economics and, in most cases, strongly contributed to their success. Farmers did not consider them as liabilities or constraints but as constituent elements of their project.

All microfarmers from our sample wished to limit their investments even if 8 of them were prepared to make large investments at certain key stages of their farm's evolution. In order to limit their investments and their dependence on external financial sources, 8 microfarmers favored self-built or second-hand equipment. As self-building and maintaining second-hand implements required specific skills and know-how, microfarmers who did not have them tended to access them through their local network. As far as possible, they also relied on their relationships within the community to borrow or rent equipment they did not use frequently instead of buying them. This showed that the quality of community integration had a direct effect on investment strategies. In the same way, in their labor organization choices, 11 
microfarmers considered that they could benefit from volunteer physical help from different members of the local community: family members, friends, neighbors or customers. However, this use of local manpower was generally moderate and occasional, mainly restricted to "peak workloads" linked to specific activities such as annual potatoes harvest or the building of a new greenhouse. Only 3 microfarms employed paid workers (Table 3). For most microfarms (9), trainees were the primary source of volunteer manpower (from $0 \%$ to $33 \%$ of global labor as shown in Table 1) in exchange for the free training to which farmers dedicated time and energy. This training function was considered as a full part of the farm activity, which contributed to the dissemination of alternative knowledge and skills.

\subsubsection{Technical and ecological management}

To design their cultivation practices microfarmers considered holistically the productive, metabolic and immune functions of their agroecosystem (Bonaudo et al. 2013). Microfarmers developed such approach through books written by alternative practitioners such as Mollison and Holmgren (1981), Fukuoka (1992), Coleman (1995), Jeavons (2001) and Fortier (2014). This way of thinking has been described by various authors in the agroecology field (Altieri 2002; Gliessman 1998; Pretty 2008). The cultivated area per unit labor of the studied microfarms (Table 1) represented from 8 to $80 \%$ of the cultivated acreage of more classic forms of diversified organic farming in France (GAB/FRAB 2009). As conventional farmers, microfarmers aimed to increase land productivity and labor productivity. For conventional farmers, this increase of productivity is seen as a way to maximize their income and to be able to cultivate a bigger surface (Hervieu and Purseigle 2013). Conversely, microfarmers wished to increase their productivity to make a livelihood out of a small cultivated area while maintaining an acceptable level of workload in line with their social aspirations. The different options chosen by microfarms to increase land and labor productivity are described in Table 3. In a systemic approach some strategies were meant to simultaneously increase land and labor productivity. For example, 12 microfarmers opted for high crop density in order to harvest more on each plot but also to reduce weeding through a dense plant cover. Eight microfarms were less motorized than classical organic market gardens because they did not use a tractor (Table 1). To increase the productivity of hand labor, these low motorized microfarms chose to use efficient manual tools such as ergonomic weeding tools or six-row manual seeders. For the same reason, some of them also chose to limit the acreage they cultivated while focusing on high added value crops such as salad greens (2) or avoiding low value crops such as winter storage potatoes (4) as shown in Table 3. 
Table 3: diversity of microfarms' main strategic choices

\begin{tabular}{|c|c|c|}
\hline Strategic category & Strategic choices & $\begin{array}{l}\text { Range of strategic choices } \\
\end{array}$ \\
\hline \multirow{3}{*}{ Marketing } & Nature of commercial channels & $\begin{array}{l}\text { vegetable box scheme (12); retail selling on the farm or in shops (8); retail selling in open air markets (3); selling to } \\
\text { restaurants or mass catering (5) }\end{array}$ \\
\hline & Combining commercial channels & only one vegetable box scheme (3); combining from to two to five different channels (11) \\
\hline & Selling period & eight (1), nine (1), ten (2), eleven (6) or twelve (4) months a year \\
\hline \multirow{4}{*}{$\begin{array}{l}\text { Community } \\
\text { integration }\end{array}$} & Non-agricultural activities & training on the farm (9); cultural activities (5); guided visits of the farm (10); commitment in local associations (7) \\
\hline & $\begin{array}{l}\text { Relying on local human resources } \\
\text { through non-monetary exchanges }\end{array}$ & $\begin{array}{l}\text { occasional physical help for heavy jobs (11); moral support from local community (12); specific skills, knowledge and } \\
\text { know-how from local people (10) }\end{array}$ \\
\hline & Collaborating with other farmers & $\begin{array}{l}\text { borrowing occasionally motorized equipment (5); commercializing with other farmers (9); using other farmers' } \\
\text { buildings (3); collective experimentation (4); sharing agricultural know-how (10) }\end{array}$ \\
\hline & Getting local organic manure & for free (7); through vegetables or labor exchanges (3); monetary way (2) \\
\hline \multirow{3}{*}{ Investment } & External financial sources accepted & government subsidies (9); bank loans (8); no external financial help (4) \\
\hline & Investment rhythm & progressive investments (6); large investments at key stages of farms' evolution (8) \\
\hline & Investment preference & favoring second-hand or self-built equipment (8); favoring new equipment (6) \\
\hline \multirow{2}{*}{$\begin{array}{c}\text { Labor } \\
\text { organization }\end{array}$} & Using paid employees & all along the production season (3); during the peak workload of spring and summer (1); never (11) \\
\hline & Using volunteers & trainees all along the production season (5); trainees during the peak workload of spring and summer (4); no trainees (5) \\
\hline \multirow{6}{*}{$\begin{array}{l}\text { Technical and } \\
\text { ecological } \\
\text { management }\end{array}$} & Increasing land productivity & $\begin{array}{l}\text { uninterrupted crop rotations (11); high crop density (12); intercropping (6); relay cropping (5);producing in winter } \\
\text { using greenhouses, frost blankets, manure hotbeds (13) }\end{array}$ \\
\hline & Increasing labor productivity & $\begin{array}{l}\text { dense plant cover limiting weed control (12); limiting soil tillage (11); tools adapted to dense plant covers such as } \\
\text { ergonomic manual weeding tools or six-row manual seeders (8); permanent plants (8) }\end{array}$ \\
\hline & Types of crops cultivated & $\begin{array}{l}\text { focusing on high added value crops (2); combining high added value crops and low added value crops (12); not growing } \\
\text { storage potatoes (4) }\end{array}$ \\
\hline & Improving soil quality and activity & no-tillage (3) or superficial tillage (8); permanent growing beds (10); soil cover with organic (8) or plastic mulches (10) \\
\hline & Renewing fertility & $\begin{array}{l}\text { at the plot scale, recycling vegetable waste or sowing green manure (13); at the farm scale, transferring to the vegetable } \\
\text { beds organic matter from others areas (7); at the territorial scale, through import of local organic matter and manure } \\
\text { (12); buying organic fertilizers (7) }\end{array}$ \\
\hline & $\begin{array}{l}\text { Preserving plants' health and controlling } \\
\text { pests }\end{array}$ & $\begin{array}{l}\text { improving natural regulations through plants and habitats diversity (13); crop rotation (14); preventive and curative } \\
\text { farm-made treatments (11); commercial organic treatments (10) }\end{array}$ \\
\hline \multirow{4}{*}{$\begin{array}{l}\text { Temporal and } \\
\text { spatial } \\
\text { organization of } \\
\text { cultivated } \\
\text { diversity }\end{array}$} & $\begin{array}{l}\text { Spatial integration of agricultural } \\
\text { biodiversity }\end{array}$ & $\begin{array}{l}\text { integrating trees, vegetables and/or animals in same spaces of the farm (7); separating vegetables, trees and/or animals } \\
\text { in distinct spaces of the farm (7) }\end{array}$ \\
\hline & $\begin{array}{l}\text { Simplifying spatial allocation of } \\
\text { vegetables with grouping criteria }\end{array}$ & botanic family (6); soil fertility needs (9) ; irrigation needs (3); season of seedlings or harvesting (6) \\
\hline & Easing rotation complexity & $\begin{array}{l}\text { building up the global immune system of the agroecosystem through biodiversity to be more flexible with rotation } \\
\text { strictness (8); distinguishing "sensitive vegetables" to sanitary disorders from "less sensitive vegetables" and following } \\
\text { strict rotation criteria only for "sensitive vegetables" (6); }\end{array}$ \\
\hline & $\begin{array}{l}\text { Reducing complexity of crop temporal } \\
\text { planning }\end{array}$ & $\begin{array}{l}\text { choosing flexible and complementary selling channels to buffer production uncertainties (11); planning one year in } \\
\text { advance with safety margins only some "key vegetables" and planting/sowing "complementary vegetables" with less } \\
\text { safety margins or throughout the production season depending on opportunities (7); no crop planning (1) }\end{array}$ \\
\hline
\end{tabular}


In accordance with classic principles of organic agriculture (Darnhofer et al. 2010), all studied microfarmers considered that soil fertility was a central issue in order to guarantee plants' productivity and health. Microfarmers implemented a wide range of strategies to improve the quality of their soil and closing nutrients and organic matter cycles at different scales (Table 3). To preserve plants' health, microfarmers used traditional practices such as crop rotation or organic treatments, mainly farm-made (plant macerations). But above all they tried to maximize natural biotic regulation through cultivated plant diversity and habitat diversity consciously created on the farm (hedgerows, trees, flowers strips, refuges for wildlife, uncultivated areas, ponds etc.). In this regard, the high level of cultivated biodiversity contributed at the same time to providing a sufficiently wide product range to be suitable for direct selling and to maintain the agroecosystem's health and resistance to disturbance (Holling 1973).

\subsubsection{Temporal and spatial organization of cultivated diversity}

Cultivated diversity was not only a key point of microfarmers' strategic choices for commercial and ecological reasons but also for social reasons. Indeed, a wide range of cultivated plants was promoted by the 14 microfarms as a way to create a pleasant landscape to work in and to improve farmer's satisfaction at work through a variety of tasks. However, organic market gardeners often perceive that a high level of cultivated diversity makes spatial and temporal organization of crops very complex (Aubry et al. 2011). This feeling was shared by the farmers we interviewed, who implemented various solutions to address this problem (Table 3). For example, 6 microfarmers judged that it was impossible to follow classic monocropping rotation criteria based on botanical family because the way in which their practice of intercropping and relay cropping mixed crops across families. Farmers chose to respect rotation criteria only for a few vegetables that they identified as "sensitive vegetables" for instance cabbages or potatoes which are sensitive to soil-borne diseases. For other vegetables judged as "less sensitive," farmers opted not to abide by strict rotation criteria in the belief that the biodiversity and intercropping practices of their farm were enough to maintain the global immune function of their agroecosystem. In an analogous way, in order to reduce the complexity of crop planning, 7 microfarmers distinguished key vegetables strongly expected by consumers at different times of the year (for example radishes in spring, tomatoes in summer and carrots in winter) and complementary vegetables which were not specifically expected by consumers but brought diversity to the commercial offer (for example kohlrabi, or fennel in summer). Only key vegetables received a strict planting plan complete with high 
safety margins before the production season. Complementary vegetables, in contrast, were planned less strictly or throughout the production season, depending on opportunities. Even in the absence of strict planning for complementary vegetables, the high number of cultivated plants at the same time made possible to offer each week enough diversity to fulfill market requirements. These examples showed that microfarmers from our sample paradoxically reduced the complexity of spatial and temporal crop planning through strategies relying on the ecological and commercial advantages of a high level of cultivated diversity. Indeed richer and healthier agroecosystems made possible to be more flexible with rotation criteria and the presence of a high number of harvestable products at any time of the year allowed microfarmers to plan less strictly their crops.

\subsection{A conceptual framework linking farmers' aspirations, perception of situation and strategic choices}

\subsubsection{Strategic choices and their determinants}

As shown in Figure 1 and Table 2, all studied microfarmers justified and explained their strategic choices referring to a wide range of aspirations and to specific constraints or opportunities perceived in their situation. It is therefore relevant to consider strategic choices in terms of coherence with these determinants as suggested by Brossier et al. (2003). For example, farm N's choice to design an agroforestry system with fruit trees and vegetables can be understood through different strategic determinants, such as the wish: to create rich agroecosystem (search for meaning and commitment); to improve landscape aesthetics through multiple plant strata (quality of life and work); to be independent from fruit producers (commercial autonomy); to supply the strong local demand for organic fruits and vegetables (opportunity of local situation); and to create shade for the market gardeners' well-being (quality of life and work) in a region with really hot summers (site constraints).

\subsubsection{Taking the interdependence of strategic choices into account}

Our analysis showed that strategic choices were closely interlinked. So it is necessary to study them in a systemic way, considering their interactions. For example, the choice of exclusively manual work (technical management) on farm $\mathrm{G}$ was related to the limitation of motorized equipment costs (investment) and to the use of trainees to meet the need for labor (labor organization). Moreover, to create a decent income without motorization, these market gardeners grew uninterrupted rotations of short-cycle vegetables and choose not to grow certain storage crops such as potatoes, which they considered to be unprofitable with manual 
growing techniques (technical management). As they perceived a large local demand for these crops, they bought potatoes from a neighboring organic producer to complement their vegetable boxes (marketing and community integration).

\subsubsection{Considering trade-offs and adaption}

Within their life project, microfarmers made trade-offs between their different aspirations. For example, microfarmers from farm $\mathrm{F}$ wanted to design a landscape where cultivated varieties would be freely spread across multiple areas in accordance with their aspiration to create a rich ecosystem. In practice, however, cultivated varieties were grown together in the same space to limit labor costs and workload, in accordance with their aspiration of reducing workload and creating a decent income. Likewise, their technical choice of using plastic mulches stemmed from a trade-off between the workload reduction allowed by this strategic choice and the wish to preserve fossil fuels required for plastic fabrication.

In the determination of strategic choices, microfarmers also adapted their aspirations to the perceived resources and constraints of their situation. For example, farm G, which had free access to horse manure from a neighboring riding school, was able to manage soil fertility sustainably by recycling organic matter at local level. Farm B, which did not perceive this opportunity, choose to allocate a part of its land to green manure production. The nature of trade-offs and adaptation varied considerably among the 14 microfarms but are essential to consider in order to understand microfarmers' strategic choices (Table 4). 
Table 4: examples of trade-offs and adaptation on the 14 microfarms

\section{Farm Aspirations in tension}

Commercial autonomy $v s$ preservation of rare resources

Besirable daily workload $v s$ preservation of rare resources

Material autonomy and decent income $v s$ fairness

Creation of rich ecosystems $v s$ change of mentalities

Desirable weekly workload and fairness $v s$ decent income

Desirable weekly workload $v s$ preservation of rare resources

Commercial autonomy $v s$

G pleasure and preservation of rare resources

H Material autonomy $v s$ decent income

Financial autonomy $v s$

I having holidays and week- The farmers do not have a lot of personal savings ends

J Aesthetics vs desirable yearly Cold climate makes impossible to grow most workload distribution vegetables outside in winter

\section{Opportunitiess/constraints perceived in situation}

Farmers in the neighborhood are ready to lend their tractor

Trade-offs and adaptation in strategic choices

The local government offers free organic matter but not enough for every grower

The farm is financially supported by sponsors for developing alternative farms which are economically viable

The two farmers are a couple

The farm was created on a meadow which brings a ot of weeds problems

A local motorized organic market gardener produces potatoes

from outside the farm (even if they are produced by a motorized colleague)

The animal manure produced in the neighborhood is not good quality

A bigger surface of greenhouse was built (even if it is mor

Bank loans are not accepted to be independent from banks but equipment is self-built progressively (even if it requires to work during some week-ends)

No greenhouse was built because it is ugly (even if vegetables can then only be sold from may to december which creates a peak workload in this period)

K Diversity of activities vs Local people do not buy a lot of vegetables in open decent income

L Decent income $v s$ fairness air markets

Local people wish to support financially the microfarm

The farmers are not confident about their technical skills as market gardeners

Local consumers wish to have fruit with their vegetables boxes varied and pleasant work to sell in open air markets)

Vegetables boxes are sold less expensive that people would be ready to pay (even if the farmer could make more money) because the farmer estimates that he is already fairly paid

Vegetables are grown in monocropping because intercropping systems would generate more workload if not well managed (even if they would bring more biodiversity)

Fruit trees rows integrated in vegetables plots are limited (even if more trees would create a nice landscape) because they are more sensitive to production uncertainties than vegetables
Vegetables are sold through a box scheme to create a decent income (even if it would be a more 


\subsubsection{A conceptual framework for a systemic approach of strategic choices}

We created a visual framework combining the different conceptual categories of strategic choices, strategic determinants and their relations already described: trade-off, adaptation, coherence and interdependence. The use of this framework is illustrated on concrete examples from farm I and $\mathrm{N}$ in Figure 2 and Figure 3. When the framework was discussed on the field, farmers and teachers highlighted that it allowed to map visually strategic choices and strategic determinants and to get a global picture of their complex links. In this regard, it can be compared as a mind map which makes possible to see a complex problem as a whole instead of analyzing each part of it separately (Buzan 1995). It was deemed credible by market gardeners because the nature and variety of the aspirations considered were in accordance with the reflection that went into designing their farms. It was judged salient because the 6 categories of strategic choices corresponded to what mattered for farmers in the management of their agroecosystem. Moreover, 30 out of 40 market gardeners said that it was sometimes difficult to take distance from their busy daily farming activities and that this framework could help them to facilitate a reflexive thinking on their strategic choices. All the teachers and advisors who were involved in the discussions about the framework told that it was crucial to help students and new farmers to develop a systemic approach on their farm but that practical tools were missing to support the teaching of systemic farming approaches. According to them, the key concepts and conceptual categories underlined by the framework could help students and farmers to "ask the good questions": "what do I really want and seek from my farming project?"; "how do I make my strategic choices coherent with what I seek?"; "how can I enjoy local opportunities and adapt to constraints?"; "which types of trade-offs am I ready to make ?". Our framework was perceived as legitimate because we took into account farmers' views, comments and criticism in all steps of the research process. As these alternative farmers valued their autonomy with regard to information and knowledge, they also appreciated the fact that the framework was non-normative and could be adapted to a wide range of aspirations and singular cases. 


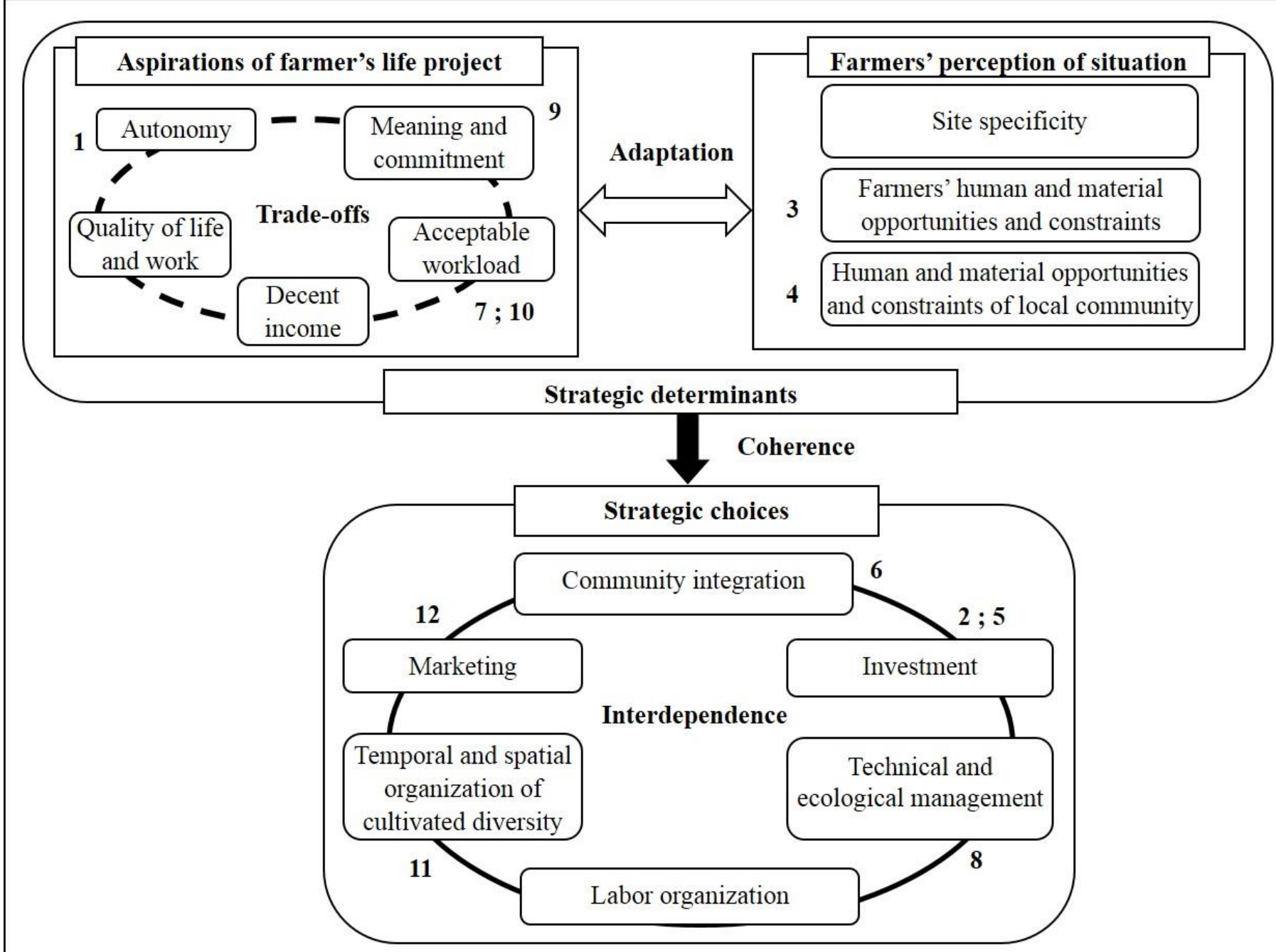

Numbers in brackets in the text are presented visually on the conceptual framework to allow a global comprehensive view of strategic choices.

For ideological reasons, these microfarmers had a strong aspiration of financial autonomy (1), which lead them to refuse bank loans (2). As they did not have a lot of personal savings (3) and perceived that some friendly neigbors had building skills (4), they decided to invest progressively in the selfbuilding of most of their equipment (5) supported and helped by their neigbors (6). As self-building equipment required time, microfarmers wished to reduce as much as possible the worload in the gardens (7). They opted for cropping practices which were supposed to limit workload: using a tiller for soil preparation, using plastic mulch to reduce weeding and growing vegetables in mocrocropping rather than intercropping (8).

These technical choices consuming fuel and limiting spatial diversity (monocropping) were a trade-off considering their environmental aspirations of creating rich ecosystems and preserving rare resources (9). As producing vegetables while self-building their equipment in the same time was exhausting, these microfarmers wanted to have long holidays in winter (10) to relax. They decided to plan their crops in order not to work in january and february (11). As consequence, they were able to sell vegetables boxes only from april to december (12). 


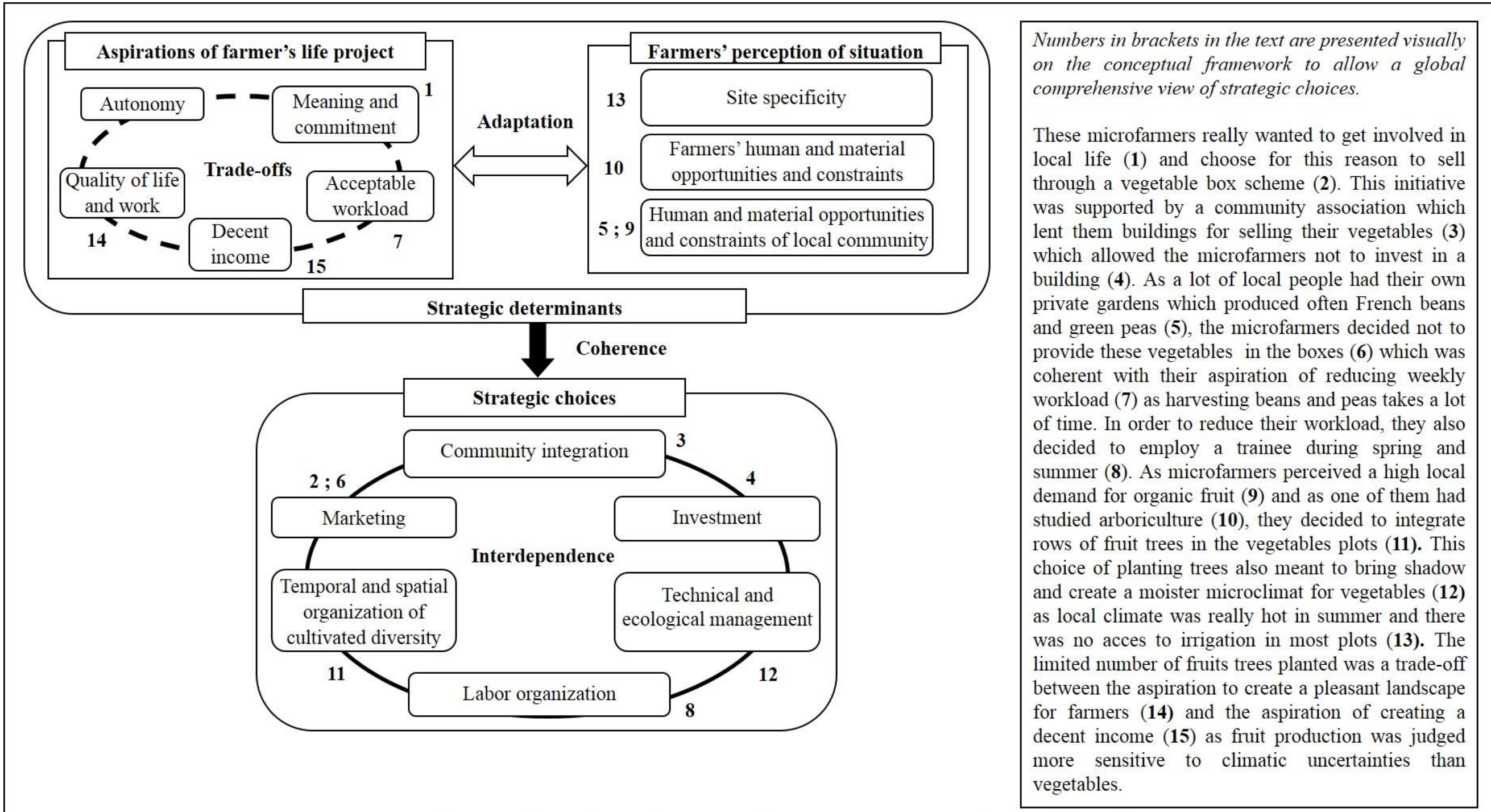

Figure 3: illustration of the conceptual framework for strategic choices of farm $\mathrm{N}$ 


\section{Discussion}

\subsection{Adaptation of our framework to other types of alternative farms}

Scientific literature shows that the aspirations highlighted in our framework: decent income and workload, quality of life, autonomy, social and environmental commitment, are shared by most alternative farmers (Holmes 2006; Beus and Dunlap 1990; Deverre and Lamine 2010; Holt Giménez and Shattuck 2011; Fernandez et al. 2013). We therefore think that the structure of our framework could be adapted to other types of alternative farms, integrating other types of aspirations as necessary. Moreover, the key concepts used in our framework: trade-offs, adaptation, coherence, interdependence, have been historically developed in systemic agronomy approaches for studying a wide range of farms, especially cereal and livestock farms (Brossier et al. 2003; Marshall et al. 2013). In this regard, we hypothesize that our framework could be suitable for other types of farms than market gardens. Concerning strategic choices categories some other categories may be needed for approaching other types of farming systems. However, we do think that the six categories we propose ((i) marketing, (ii) community integration, (iii) investment, (iv) labor organization, (v) technical and ecological management, (vi) temporal and spatial organization of cultivated diversity) are relevant for other alternative farms. Indeed, classical agronomic frameworks assume that all farming systems have to make strategic choices about marketing, investment, labor organization and technical management (Brossier et al. 2003; Marshall et al. 2013). Furthermore, as alternative farms seek to contribute to the vitality or rural communities, respect the environment and value diversity (Holmes 2006; Beus and Dunlap 1990; Deverre and Lamine 2010; Holt Giménez and Shattuck 2011; Fernandez et al. 2013; Ponisio et al, 2015), they tend to rely more on local networks, to develop a holistic approach of their agroecosystem and to be challenged by the management of complex diversified systems. The original focus in our work on specific strategic choices concerning community integration, ecological management and organization of cultivated diversity could therefore be more generally convenient for other alternative farming systems.

\subsection{Assessing and supporting alternative farms viability}

Our qualitative study was meant to be a first step in the development of a practical tool to support microfarmers in the design of strategic choices which ensure the viability of their farms. In the introduction, we gave a preliminary theoretical definition of viability as farms' internal economic and social sustainability (Yunlong and Smit 1994; Hansen and Jones 1996; 
Ba and Aubry 2011). During the interviews, microfarmers told us that their aptitude and desire to continue their farming activity would depend to the extent they would be able to fulfill their wide range of material and immaterial aspirations over the time. Based on this work, we propose a definition of farm's viability as the possibility for farmers to live on a long-term basis in accordance with their material and immaterial needs and values. We think that this generic definition should be operationalized specifically for each farm because our work showed that aspirations varied among the farms. Assessing and supporting the viability of a farm thus requires an understanding of the specific needs and values of that farm, for example the minimal level of income required to sustain farmers' lifestyle, the maximal weekly workload acceptable, and the environmental and social aspirations which make sense for the farmer.

This understanding could lead to define for each farm quantitative and qualitative constraints which need to be respected to guarantee the farm's viability. Our work has shown that microfarmers did not wish to optimize a few criteria (for example their profit) but to guarantee an acceptable fulfillment of a large variety of criteria. We therefore think that mathematical approaches to viability could be relevant for supporting their decision-making. The mathematical theory viability (Aubin 1991; Cury et al. 2005; Sabatier 2010) assumes that a system is viable if it stays in a domain of multiple constraints over time. Mathematical algorithms have been developed to explore all strategies which allow a system to stay within a set of given constraints, as distinct from optimization approaches that highlight only the best strategies to fulfill a limited number of criteria by problem-solving algorithms (Sabatier 2010; Martin et al. 2013). However, viability algorithms require quantitative data and a dynamic description of the studied systems. As our conceptual framework provides only a qualitative and static vision of the farm, further reflection and data collection will be carried out to develop dynamic models of microfarms depending on the strategic choices they make.

\subsection{Furthering the understanding of trade-offs between aspirations}

Our work has shown that farmers' strategic choices are the result of their perception of situation and trade-offs between their aspirations. The modalities of these trade-offs require further investigation. The framework of multifunctionality of agriculture (MFA) aims to quantify the value of different functions, goods and services provided by farming systems, in order to optimize the trade-offs between them for increased sustainability (Gómez Sal and González García 2007; Huang et al. 2015). The MFA approach distinguishes the on-farm 
effects and the off-farm effects of the identified functions. On-farm effects are seen as farmer's private goods, whereas off-farm effects are perceived as common or public goods (Huang et al. 2015). Based on this theoretical consideration, it would be possible to consider alternative farmers' on-farm and off-farm aspirations. As alternative farmers strongly wish to have a positive impact on social and environmental global welfare (off-farm aspirations), they may neglect or sacrifice their income or their quality of life (on-farm aspirations) which can put the farm's viability at risk (Bon et al. 2010). Conversely, the microfarmers we studied argued that their personal welfare was a fundamental condition of their contribution to collective welfare and wished to reconcile both in their strategic choices. MFA approaches have considered varied economic, social and environmental off-farm effects but on-farm effects are usually limited to farmer's costs and profits (Buysse et al. 2007; Huang et al. 2015). To reach a deeper understanding of trade-offs in alternative farming systems, a wider range of on-farm aspirations should be considered.

\section{Conclusion}

Our case study of 14 market gardening microfarms in northern France has shown that the strategic choices of these alternative farmers were coherent with a global life project defined by strong social and environmental aspirations rather than profit maximization. Classical agronomic frameworks are thus not suited to the analysis and assessment of such strategic choices. Through a qualitative analysis, we developed a conceptual framework which takes into account not only farmers' usual aspirations, such as generating a decent income and maintaining an acceptable workload, but also their search for autonomy, quality of life, meaning and commitment. As these aspirations were sometimes in tension, our framework highlights the need to consider trade-offs between them. This framework also underlines the necessity to consider farmers' perception and adaptation to local opportunities and constraints because microfarmers based their project on close relationships with community and wished to create agroecosystems in accordance with local conditions. Moreover, it emphasizes the necessity to approach microfarmers' strategic choices through their interdependence because microfarms' design was underpinned by holistic thinking in alignment with their sources of inspiration, such as organic agriculture, natural farming and permaculture. Our conceptual framework was discussed with market gardening professionals on the field and was judged relevant to stimulate systemic and reflexive thinking on microfarmers' strategic choices. We think that this framework could be adapted to other types of alternative farming systems that 
promote social and environmental aspirations, adaptation to local context, and holistic thinking. This qualitative framework could be a base for the development of dynamic modelling to better understand the long-term viability of of alternative farms. Our work suggests that it would be especially relevant to examine the impacts on farm viability of tradeoffs between farmers' on-farm (farmer's welfare) and off-farm (society welfare).

\section{References}

Agence bio (French national agency for organic agriculture). 2014. La bio en France, de la production à la consommation.

http://www.agencebio.org/sites/default/files/upload/documents/4_Chiffres/BrochureC

C/CC2014_chap4_France.pdf [Accessed 2015, June 18]

Altieri, M. A. 1989. Agroecology: A new research and development paradigm for world agriculture. Agriculture, Ecosystems \& Environment 27 (1-4):37-46. doi:10.1016/01678809(89)90070-4.

Altieri, M. A. 2002. Agroecology: the science of natural resource management for poor farmers in marginal environments. Agriculture, Ecosystems \& Environment 93 (1-3): 1-24. doi:10.1016/S0167-8809(02)00085-3.

Aubin, J. P. 1991. Viability theory. Systems \& control: Foundations \& applications. Birkhäuser, Boston. doi 10 (1007): 978-0.

Aubry, C., F. Bressoud and C. Petit. 2011. Les circuits courts en agriculture revisitent-ils l'organisation du travail dans l'exploitation? In Le travail en agriculture: son organisation et ses valeurs face à l'innovation, 304 p. Ed: L'Harmattan. http://hal.archives-ouvertes.fr/hal-00939711.

Ba, A. and C. Aubry. 2011. Diversité et durabilité de l'agriculture urbaine: une nécessaire adaptation des concepts?. Norois 221 (4): 11-24.

Beaud, S. and F. Weber. 2010. Guide de l'enquête de terrain: produire et analyser des données ethnographiques. $4 \mathrm{e}$ éd. augmentée. 1 vol. Grands repères. Paris: la Découverte.

Benoit, M., J. Brossier, E. Chia, E. Marshall, M. Roux, P. Morlon, and B. Teilhard de Chardin. 1988. Diagnostic global d'exploitation agricole: une proposition méthodologique. SAD Etudes et Recherches. no. 12. http://agris.fao.org/agrissearch/search.do?recordID=FR19890022087.

Beus, C. E. and R. E. Dunlap. 1990. Conventional versus Alternative Agriculture: The 
Paradigmatic Roots of the Debate. Rural Sociology 55(4): 590-616. doi:10.1111/j.1549-0831.1990.tb00699.x.

Bodiou, D. 2009. Steve Groff, une stratégie de couverture permanente des sols. Techniques Culturales Simplifiées 52: 34-36.

Boltanski, L. and L. Thévenot. 2006. On Justification: Economies of Worth. Princeton University Press.

Bonaudo, T. , A. B. Bendahan, R. Sabatier, J. Ryschawy, S. Bellon, F. Léger, D. Magda and M. Tichit. 2013. Agroecological principles for the redesign of integrated croplivestock systems. European Journal of Agronomy, 9. doi:10.1016/j.eja.2013.09.010.

Bon, N., E. Lanciano, C. Hérault-Fournier and P. Aubrée. 2010. Diversité des logiques de travail dans les exploitations maraîchères en circuits courts. http://halshs.archivesouvertes.fr/halshs-00676845 (accessed May 15, 2014).

Bourdieu, Pierre. 1992. Réponses: pour une anthropologie réflexive. Ed du Seuil, Paris.

Boutinet, J. P. 2012. Anthropologie du projet. Presses universitaires de France, Paris.

Bressoud, F., M. Navarrete and C. Mazollier. 2009. Le maraîchage et la production de légumes biologiques: ajuster la production et la commercialisation. In Transitions vers l'agriculture biologique. eds C. Lamine and S. Bellon, 75-101. Ed Quae, Educagri, France.

Brossier, J., E. Chia and E. Marshall. 2003. Gestion de l'exploitation agricole familiale: éléments théoriques and méthodologiques. Educagri, Dijon.

Brudermann, T., K. Reinsberger, A. Orthofer, M. Kislinger, and A. Posch. 2013. Photovoltaics in agriculture: A case study on decision making of farmers. Energy Policy 61: 96-103.

Brummel, R. F. and K. C. Nelson. 2014. Does multifunctionality matter to US farmers? Farmer motivations and conceptions of multifunctionality in dairy systems. Journal of Environmental Management 146 (décembre): 451-62.

Buzan T. 1995. The Mind Map Book. BBC Books, London

Buysse, J., G. Van Huylenbroeck and L. Lauwers. 2007. Normative, positive and econometric mathematical programming as tools for incorporation of multifunctionality in agricultural policy modelling. Agriculture, ecosystems \& environment 120 (1): 70-81.

Cash, D.W., W.C. Clark, F. Alcock, N. M. Dickson, N. Eckley, D. H. Guston, J. Jäger and R. B. Mitchell. 2003. Knowledge Systems for Sustainable Development. Proceedings of the National Academy of Sciences 100 (14): 8086-91. doi:10.1073/pnas.1231332100. 
Chia, E., J. Brossier and E. Marshall. 1991. Démarche clinique et décisions : une méthode de recherche en gestion. Économie rurale 206 (1): 29-36. doi:10.3406/ecoru.1991.4235.

Coleman, E. 1995. The New Organic Grower: A Master's Manual of Tools and Techniques for the Home and Market Gardener, 2nd Edition. Revised and expanded second edition edition. White River Junction, Vt: Chelsea Green Publishing. 1999. Four-Season Harvest: Organic Vegetables from Your Home Garden All Year Long, 2nd Edition. Subsequent edition. White River Junction, Vt: Chelsea Green Publishing.

— 2009. The Winter Harvest Handbook: Year Round Vegetable Production Using Deep Organic Techniques and Unheated Greenhouses. White River Junction, Vt: Chelsea Green Publishing.

Cury, P. M., C. Mullon, S. M. Garcia and L. J. Shannon. 2005. Viability theory for an ecosystem approach to fisheries. ICES Journal of Marine Science: Journal du Conseil 62 (3): $577-84$.

Dalgaard, T., N. J. Hutchings and J. R. Porter. 2003. Agroecology, scaling and interdisciplinarity. Agriculture, Ecosystems \& Environment 100 (1): 39-51. doi:10.1016/S0167-8809(03)00152-X.

Darnhofer, I., T. Lindenthal, R. Bartel-Kratochvil and W. Zollitsch. 2010. Conventionalisation of Organic Farming Practices: From Structural Criteria towards an Assessment Based on Organic Principles. A Review. Agronomy for Sustainable Development 30 (1): 67-81. doi:10.1051/agro/2009011.

Deverre, C. and C. Lamine. 2010. Les systèmes agroalimentaires alternatifs. Une revue de travaux anglophones en sciences sociales. Économie rurale. Agricultures, alimentations, territoires 317: 57-73.

Eisenhardt, K. M. 1989. Building theories from case study research. Academy of management review 14 (4): 532-50.

Elo, S. and H. Kyngäs. 2008. The Qualitative Content Analysis Process. Journal of Advanced Nursing 62 (1): 107-15. doi:10.1111/j.1365-2648.2007.04569.x.

Ferguson, R. S. and S. T. Lovell. 2014. Permaculture for agroecology: design, movement, practice, and worldview. A review. Agronomy for Sustainable Development 34 (2): $251-74$.

Fernandez, M., K. Goodall, M. Olson and V. Ernesto Méndez. 2013. Agroecology and Alternative Agri-Food Movements in the United States: Toward a Sustainable Agri- 
Food System. Agroecology and Sustainable Food Systems 37 (1): 115-26. doi:10.1080/10440046.2012.735633.

Fortier, J. M. 2014. The Market Gardener: A Successful Grower's Handbookfor Small-Scale Organic Farming. New Society Publishers, Canada.

Francis, C., G. Lieblein, S. Gliessman, T. A. Breland, N. Creamer, R. Harwood, L. Salomonsson et al. 2003. Agroecology: The Ecology of Food Systems. Journal of Sustainable Agriculture 22 (3): 99-118. doi:10.1300/J064v22n03_10.

Fukuoka, M. 1992. One-Straw Revolution: Introduction to Natural Farming. Other India Press, Mapusa.

Girard, N., M. Duru, L. Hazard and D. Magda. 2008. Categorising farming practices to design sustainable land-use management in mountain areas. Agronomy for sustainable development 28 (2): $333-43$.

Gliessman, S.R. 1998. Agroecology: Ecological Processes in Sustainable Agriculture. Ann Arbor Press, Chelsea.

Gómez Sal, A. and A. González García. 2007. A comprehensive assessment of multifunctional agricultural land-use systems in Spain using a multi-dimensional evaluative model. Agriculture, Ecosystems \& Environment, Multifunctionality of Agriculture: Tools and Methods for Impact Assessment and Valuation, 120 (1): 82-91. doi:10.1016/j.agee.2006.06.020.

GRAB/FRAB (French national federation for organic farming). 2009. S'installer en maraîchage bio. Fiches techniques Fruits et Légumes $n^{\circ} 17$. http://www.agrobiobretagne.org/wp-content/uploads/2010/09/Installation.pdf [Accessed 2015, January 23]

Greiner, R. and D. Gregg. 2011. Farmers' intrinsic motivations, barriers to the adoption of conservation practices and effectiveness of policy instruments: Empirical evidence from northern Australia. Land Use Policy 28 (1): 257-65.

Hansen, J. W. and J. W. Jones. 1996. A systems framework for characterizing farm sustainability. Agricultural Systems 51 (2): 185-201. doi:10.1016/0308-521X(95)00-5.

Hernandez, X. E. 1977. Agroecosistemas de Mexico - Contribución a la enseñanza, la investigación y la divulgación agrícola. Ed. Colegio de Postgrados Chapingo, Mexico.

Hervé-Gruyer, C. and P. 2014. Permaculture : guérir la Terre, nourrir les hommes. Arles: ACTES SUD.

Hervieu, B. and F. Purseigle. 2013. Sociologie des mondes agricoles. Paris, France: A. Colin 
Holling, C. S. 1973. Resilience and Stability of Ecological Systems. Annual Review of Ecology and Systematics 4 : 1-23.

Holmes, J. 2006. Impulses towards a multifunctional transition in rural Australia: Gaps in the research agenda. Journal of Rural Studies 22 (2): 142-60. doi:10.1016/j.jrurstud.2005.08.006.

Holmgren, D. 2002. Permaculture: Principles and Pathways beyond Sustainability. 11.1.2002 edition. Hepburn, Vic: Holmgren Design Services.

Holt Giménez, E. and A. Shattuck. 2011. Food crises, food regimes and food movements: rumblings of reform or tides of transformation?. Journal of Peasant Studies 38 (1): 109-44. doi:10.1080/03066150.2010.538578.

Howard, A. 1940. An Agricultural Testament. Oxford University Press, London.

Howley, P., E. Dillon and T. Hennessy. 2013. It's Not All about the Money: Understanding Farmers' Labor Allocation Choices. Agriculture and Human Values 31 (2): 261-71. doi:10.1007/s 10460-013-9474-2.

Huang, J., M. Tichit, M. Poulot, S. Darly, S. Li, C. Petit and C. Aubry. 2015. Comparative review of multifunctionality and ecosystem services in sustainable agriculture. Journal of Environmental Management 149: 138-47. doi:10.1016/j.jenvman.2014.10.020.

Jeavons, J. C. 2001. Biointensive Sustainable Mini-Farming: II. Perspective, Principles, Techniques and History. Journal of Sustainable Agriculture 19 (2): 65-76. doi:10.1300/J064v19n02_07.

Jeunes Agriculteurs. 2013. Enquête nationale sur les hors cadres familiaux en agriculture, qui sont-ils et quels sont leurs besoins? http://www.jeunes-agriculteurs.fr/deveniragriculteur/item/677-demain-je-serai-paysan-?-etat-des-lieux-des-installations-deshors-cadres-familiaux [Accessed 2015, October 12]

Landais, E., J.P. Deffontaines and M. Benoit. 1988. Les pratiques des agriculteurs Point de vue sur un courant nouveau de la recherche agronomique. Études rurales 109: 125-58.

Laurent, C., F. Maxime, A.Mazé and M. Tichit. 2003. Multifonctionnalité de l'agriculture and modèles de l'exploitation agricole. Économie rurale 273 (1): 134-52. doi:10.3406/ecoru.2003.5395.

Le Moigne, J. L. 1984. La Théorie du système général: théorie de la modélisation. 2e éd. Systèmes-décisions. Paris: Presses universitaires de France.

Marshall, E., J. R. Bonneviale and I. Francfort. 2013. Fonctionnement et diagnostic global de l'exploitation agricole: une méthode interdisciplinaire pour la formation et le 
développement. Educagri éditions, Dijon.

Martin, G., R. Martin-Clouaire and M. Duru. 2013. Farming system design to feed the changing world. A review. Agronomy for Sustainable Development 33: 131-139. doi:10.1007/s13593-011-0075-4

Martin, G. 2015. A conceptual framework to support adaptation of farming systems Development and application with Forage Rummy. Agricultural Systems 132: 52-61. doi:10.1016/j.agsy.2014.08.013.

McCown, R.L., P.S. Carberry, Z. Hochman, N.P. Dalgliesh and M.A. Foale. 2009. Reinventing model-based decision support with Australian dryland farmers. 1. Changing intervention concepts during 17 years of action research. Crop and Pasture Science 60 (11): 1017-30.

Méndez, V. E., C. M. Bacon and R. Cohen. 2013. Agroecology as a Transdisciplinary, Participatory, and Action-Oriented Approach. Agroecology and Sustainable Food Systems 37 (1): 3-18. doi:10.1080/10440046.2012.736926.

Miles, M. B. and A. M. Huberman. 1984. Qualitative Data Analysis: A Sourcebook of New Methods. SAGE Publications Inc, Beverly Hills.

Milleville, P.. 1987. Recherches sur les pratiques des agriculteurs. Les cahiers de la Recherche Développement 16: 3-7.

Mollison, B. and D. Holmgren. 1981. Permaculture One: A Perennial Agriculture for Human Settlements. International Tree Crop Institute, USA.

Morin, E. 2005. Introduction à la pensée complexe. Éd. du Seuil, Paris.

Mzoughi, N. 2014. Do organic farmers feel happier than conventional ones? An exploratory analysis. Ecological Economics 103: 38-43. doi:10.1016/j.ecolecon.2014.04.015.

Navarrete, M.. 2009. How do Farming Systems Cope with Marketing Channel Requirements in Organic Horticulture? The Case of Market-Gardening in Southeastern France. Journal of Sustainable Agriculture 33 (5): 552-65. doi:10.1080/10440040902997785.

Olivier de Sardan, J.P. 2009. La rigueur du qualitatif: les contraintes empiriques de l'interprétation socio-anthropologique. 1 vol. Anthropologie prospective, $\mathrm{n}^{\circ} 3$. Louvain-la-Neuve: Academia-Bruylant.

Pourias, J., C. Aubry and Eric Duchemin. 2015. Is Food a Motivation for Urban Gardeners? Multifunctionality and the Relative Importance of the Food Function in Urban Collective Gardens of Paris and Montreal. Agriculture and Human Values April: 1-17. doi:10.1007/s 10460-015-9606-y. 
Pretty, J. 2013. Agricultural sustainability: concepts, principles and evidence. Philosophical Transactions of the Royal Society B: Biological Sciences 363: 447-465

Sabatier, R.. 2010. Arbitrages multi-échelles entre production agricole et biodiversité dans un agroécosystème prairial. Doctoral dissertation, AgroParisTech. http://www.theses.fr/2010AGPT0064. [Accessed 2015, October 22]

Schmitzberger, I., T. Wrbka, B. Steurer, G. Aschenbrenner, J. Peterseil, and H. G. Zechmeister. 2005. How farming styles influence biodiversity maintenance in Austrian agricultural landscapes. Agriculture, Ecosystems \& Environment 108 (3): 274-90.

Siggelkow, N. 2007. Persuasion with case studies. Academy of Management Journal 50 (1): 20-24.

Whitefield, P. 2004. Earth Care Manual: A Permaculture Handbook for Britain \& Other Temperate Climates. Permanent Publications, UK.

Yin, R. K. 2009. Case study research: design and methods. Sage, Los Angeles, London, New-Dehli.

Yunlong, C. and B. Smit. 1994. Sustainability in agriculture: a general review. Agriculture, Ecosystems \& Environment 49 (3): 299-307. doi:10.1016/0167-8809(94)90059-0. 